REFERENCES

Benedict, F. G. \& Carpenter, T. M. (1918). Publ. Carneg. Instn, no. 26 r.

Booth, G. \& Strang, J. M. (1936). Arch intern. Med. 57, 533.

Brobeck, J. R. (1948). Yale f. Biol. Med. 20, 545.

Brobeck, J. R. (1956). Int. physiol. Congr. xx. Brussels, p. 133.

Burton, A. C. \& Edholm, O. G. (I955). Man in a Cold Environment. London: Edward Arnold.

Magnus-Levy, A. (1894). Pflüg. Arch. ges. Physiol. 55, г.

Magnus-Levy, A. (1907). In Metabolism and Practical Medicine, p. 208. [C. von Norden, editor.] English translation. London: W. Heinemann.

Rubner, M. (1902). Quoted by Magnus-Levy (1907).

Strang, J. M. \& McCluggage, H. B. (1931). Amer. F. med. Sci. 182, 49.

Strominger, J. L. \& Brobeck, J. R. (1953). Yale Y. Biol. Med. 25, 383 .

Wilhelmj, C. M., Bollman, J. L. \& Mann, F. C. (r928). Amer. F. Physiol. 87, 497.

\title{
The energy expenditure and food intake of middle-aged Glasgow housewives and their adult daughters
}

\author{
By J. V. G. A. DURNIN, ELAINE C. BLAKE AND J. M. BROCKWAY \\ Institute of Physiology, University of Glasgow
}

(Received 8 October I956)

During recent years there has been a very considerable increase in the available information on energy expenditure in relation to activity. Measurements have been made on individuals of differing ways of life in several countries. Yet few studies have attempted to cover the whole $24 \mathrm{~h}$ period, as opposed to estimates covering the working time only. The scarcity of such studies is probably mainly due to their administrative difficulty and their cost. From this point of view, soldiers present fewer problems than a comparable group of civilians; there have been several excellent field studies on energy intake and expenditure, especially by the U.S., British, Canadian and Australian Armies. Some of these reports, and similar ones in other countries, are published for a restricted circulation, but examples of a few generally available are those by Sargent, Sargent, Johnson \& Stolpe (1954, 1955), Edholm, Fletcher, Widdowson \& McCance (1955), Consolazio, Pollack, Crowley \& Goldstein (1956) and by Buskirk, Kreider, Brebbia, Morana, Daniels, Welch, Mann, Insull \& Friedemann ( 956 ). However, information about civilians is so limited that the Committees on Calorie Requirements of the Food and Agriculture Organization (FAO) of the United Nations have had great difficulty in formulating their recommendations, especially when dealing with calorie allowances for women and with the appropriate decreases in caloric allowances for adults in relation to advancing age. Though some limited observations have been made on the effect of age on the food intake of men, there are few similar data for women. The estimates of calorie requirements and the decrement for age, where women are concerned, have perforce been largely based on guesswork and on the relatively few dietary studies reported. 
In Britain, two surveys have recently been made of the food intake and energy expenditure of individual civilians. The first was a pilot-study on a small number of male university students (Passmore, Thomson \& Warnock, 1952). The second was made on underground coal-face miners and office clerks (Garry, Passmore, Warnock \& Durnin, 1955). No such surveys on women, involving measurements of energy expenditure, have been described; yet housewives probably form the largest single occupational group in the country today.

We have estimated the energy expended and the food eaten by a group of middleaged, middle-class housewives and by their grown-up, working daughters. Most women employed gainfully in this country work as shop assistants, in offices, or in light industry. For convenience we chose girls employed in a large departmental store in Glasgow. Thus all the daughters had similar occupations. They formed a homogeneous group for comparison with their mothers, the housewives, thus providing two age groups with similar social backgrounds and dietary habits.

\section{METHODS}

General. Twelve mothers and their twelve daughters were studied, each pair throughout 7 consecutive days. The mean age of the mothers was $5 \mathrm{I}$ years and their mean weight was $\mathrm{I}_{42} \mathrm{Ib}$. $(64 \cdot 4 \mathrm{~kg})$. The daughters had a mean age of 20 years and a mean weight of $125 \mathrm{lb}$. $(56.8 \mathrm{~kg})$. Details are given in Table $\mathrm{I}$. All the families lived in the Glasgow area, mostly in houses with stairs. Nine of the homes consisted of four rooms excluding the kitchen and bathroom, one was three-roomed, and two had five rooms. The size of the families varied, but only in one family were there young children. No housewife did any work outside her own home. One (Mrs J.) had a woman to help with the 'heavy' work for a few hours weekly. With only one exception (Mrs St.) all possessed vacuum cleaners. Three used washing machines, but only one of these had an automatic wringer attached. None owned dish-washing machines, automatic irons or floor-polishers. Large departmental stores are much the same in every country, and the shop-girls were drawn from a variety of departments, which

Table I. Ages, heights and weights of the housewives and their daughters

\begin{tabular}{|c|c|c|c|c|}
\hline \multicolumn{5}{|c|}{ Housewives } \\
\hline Subject & $\begin{array}{c}\text { Age } \\
\text { (years) }\end{array}$ & $\begin{array}{l}\mathrm{He} \\
\text { (ft. }\end{array}$ & $\begin{array}{l}\text { ight } \\
\text { in.) }\end{array}$ & $\begin{array}{l}\text { Weight } \\
\text { (lb. } \quad(\mathrm{kg}))\end{array}$ \\
\hline Mrs B. & $5^{8}$ & 5 & & $148(67 \cdot 0)$ \\
\hline Mrs C. & 52 & & $2 \frac{1}{2}$ & $143\left(65^{\circ} 0\right)$ \\
\hline Mrs D. & 51 & 5 & 3 & $153(69 \cdot 5)$ \\
\hline Mrs Dr. & $6 I$ & 5 & 6 & $145(66 \cdot 0)$ \\
\hline Mrs Du. & 51 & 5 & $3 \frac{1}{2}$ & I32 $(60 \cdot 0)$ \\
\hline Mrs G. & 46 & 5 & $3 \frac{1}{2}$ & $129(58 \cdot 5)$ \\
\hline Mrs H. & 53 & 5 & 3 & I $32(60 \cdot 0)$ \\
\hline Mrs J. & 45 & 5 & 3 & I $45(66 \cdot 0)$ \\
\hline Mrs McQ. & 53 & 5 & 0 & $161(73.0)$ \\
\hline Mrs S. & 51 & 5 & 4 & $142(64 \cdot 5)$ \\
\hline Mrs St. & 50 & 4 & I I $\frac{1}{2}$ & I62 (73.5) \\
\hline Mrs W. & 45 & 5 & $\mathrm{I} \frac{1}{2}$ & $108\left(49^{\circ} 0\right)$ \\
\hline Mean & $5 \mathrm{I}$ & 5 & 3 & I $42(64.4)$ \\
\hline
\end{tabular}

\begin{tabular}{|c|c|c|c|c|}
\hline \multicolumn{5}{|c|}{ Daughters } \\
\hline Subject & $\begin{array}{c}\text { Age } \\
\text { (years) }\end{array}$ & $\begin{array}{l}\text { Hei } \\
\text { (ft. }\end{array}$ & $\begin{array}{l}\text { ght } \\
\text { in.) }\end{array}$ & $\begin{array}{l}\text { Weight } \\
\text { (lb. (kg)) }\end{array}$ \\
\hline Jean B. & 20 & 5 & 4 & I I $5(52 \cdot 0)$ \\
\hline Margaret C. & 25 & 5 & $0 \frac{1}{2}$ & II $7(53.0)$ \\
\hline Margaret D. & 20 & 5 & 6 & I I $4(5 \mathrm{I} \cdot 5)$ \\
\hline Elma Dr. & 16 & 5 & 5 & I $40(63.5)$ \\
\hline Muriel Du. & 26 & 5 & 6 & $125(56.5)$ \\
\hline Sheila G. & 17 & 5 & 7 & $124(56 \cdot 0)$ \\
\hline Nada $\mathrm{H}$. & 23 & 5 & 9 & I6I $(73 \cdot 0)$ \\
\hline Evelyn J. & 18 & 5 & $2 \frac{1}{2}$ & I I $(53.5)$ \\
\hline Nan McQ. & 20 & 5 & 6 & I $55(70.5)$ \\
\hline Meta S. & 27 & 5 & 5 & I $20\left(54^{\circ} 5\right)$ \\
\hline Rita St. & I7 & 5 & 0 & IOI $(46 \cdot 0)$ \\
\hline Jeanette W. & I7 & 5 & $O \frac{1}{2}$ & I I $5(52 \cdot 0)$ \\
\hline Mean & 20.5 & 5 & 4 & $\mathrm{I} 25(56 \cdot 8)$ \\
\hline
\end{tabular}


included 'frocks', 'corsets', 'children's clothes', 'cosmetics', 'manicuring' and 'hairdressing'; this last department was a very busy one. The girls were employed solely in attending to customers and no strenuous muscular effort, apart from going up and down stairs, was needed.

Measurement of food intake. The total food intake of each mother and of each daughter was measured daily for a week. This was done by the individual inventory method, all the food taken by each subject being weighed and recorded. Before the survey began the purpose and methods of the investigation were fully explained to each subject in her own home. The mothers and daughters were taught how to measure and weigh their food accurately. Special dietary spring balances were left in each home. Beakers were provided for measuring fluids, and plastic containers for easy weighing of such foods as jam, sugar and butter. Details of these methods have been more fully described in an earlier study (Garry et al. I955). The quantities of food taken were recorded in log-books at the time of eating. Many of the shop-girls had lunch or snacks in the store canteen; a dietitian was present there at meal-times to weigh and record the food they ate. One dietitian was responsible for one subject only, either mother or daughter, during the week of observation. She visited the home once daily, usually at or immediately after a main meal, checked the log-book, noted recipes, and generally helped with any difficulties.

Apart from food taken in the home or canteen, the weights of chocolates, biscuits, cakes and other extras bought outside were obtained by buying similar quantities and weighing them. Plate waste was weighed and subtracted from the original weight of the portion of food. The energy value of the food and the content of protein, fat, carbohydrate, minerals and vitamins were estimated from tables supplied by the Ministry of Agriculture, Fisheries and Food. The nutrient-conversion factors in these tables are based largely on those compiled by the Medical Research Council: Accessory Food Factors Committee (1945) with appropriate alterations, especially for foods containing flour, to bring the values into line with recent changes in the composition of foods. The use of the tables is discussed by Garry et al. (1955). The nutrient value of the diet of each woman was calculated separately for each of the 7 days.

Estimate of energy expenditure. During the week when the food intake was being measured observations were made on the expenditure of energy. Each woman kept an exact record of the time spent on each activity throughout the entire week. This record was kept in special note-books and in the simplified form detailed by Garry et al. (1955). Though the procedure was irksome to the women, they were most co-operative and provided an accurate and detailed account of how their days were spent. Every subject was visited daily by one of the authors to ensure that the record was being kept properly and to smooth away any difficulties. With the Max-Planck respirometer (Müller \& Franz, 1952), measurements of the energy cost of the various tasks were made by indirect calorimetry. These respirometers were calibrated by the method previously described (Durnin, 1955). The total energy expenditure was calculated by multiplying the number of minutes spent in each activity by the 'calorie value' of that activity and the figures thus obtained were then added together. The energy expenditure during sleep was taken to be equivalent to the basal metabolism (cf. Passmore \& 
Durnin, 1955), estimated from Fleisch's (1951) tables. It was not possible to make measurements of the expenditure of energy during all the manifold household activities of all the housewives. However, several estimations were made on many types of domestic work on some young experienced housewives of widely differing weights. These values for the household tasks were applied, with certain adjustments, when it was not possible to measure the energy expenditure of a mother engaged on a particular activity. The adjustments were based on previous results obtained for the mother, on her weight and on the judgement of one of the authors (J. D.) of the rate at which she normally carried out her work. At first it was hoped to use the pulmonary ventilation as an index of the energy expenditure, as advocated by Durnin \& Edwards (1955). Unfortunately pulmonary ventilation for most housewives was often about $151 . / \mathrm{min}$ or even less, at which level it is probably no true guide to energy expenditure.

Both before and during the actual survey it was impressed upon the subjects that they must behave during the survey exactly as they would have done under ordinary circumstances. We are reasonably satisfied that they did so.

\section{RESULTS}

Calorie balance. Table 2 shows the daily calorie intakes and expenditures by the housewives and by their daughters, and the mean daily values for the two groups. The agreement between mean daily intakes and expenditures of each group was exceptionally good, although there were quite often marked differences between the daily intake and expenditure of energy by the individual. The variation in energy balance in this, and in some other similar surveys, will be discussed more fully in another paper.

Energy expenditure. In Fig. I, the pattern of the main activities of the two groups is shown. In order to give a better comparison between the two groups of subjects, all the many domestic tasks done while standing have been put under the one heading of 'standing activities', with the one exception of 'shopping'. This arrangement allows comparison between the times spent and the calories expended in 'similar activities' by the housewives and the daughters. Fig. I shows the remarkable similarity of the two sets of results. The girls spent a little longer in bed, in washing, dressing and other personal necessities, and in walking; but for all practical purposes, the energy expended in everything except walking was almost identical for mothers and daughters. The extra energy used by the girls in walking accounted very largely for their greater total energy expenditure. Few mothers or daughters indulged in any strenuous recreational activity. Walking accounted for most of the energy expended by the mothers outside the home, although one (Mrs W.) spent part of one evening country-dancing and another (Mrs H.) spent a few minutes each morning doing physical exercise and had a short weekly swim. The daughters also spent much of their energy during recreation in walking. However, one of the girls (R. St.) regularly spent four evenings a week dancing, another (E. J.) danced twice in the week, one (E. Dr.) occasionally went iceskating, and M. D. played badminton once weekly. Most went to the cinema once or twice a week. 
Table 2. Individual and mean daily values for energy intake and expenditure (Cal.) of middle-aged housewives and their adult daughters

\begin{tabular}{|c|c|c|c|c|c|c|c|c|c|}
\hline \multicolumn{2}{|l|}{$\begin{array}{c}\text { Subject } \\
\text { Housewives: }\end{array}$} & Monday & Tuesday & Wednesday & Thursday & Friday & Saturday & Sunday & Mean \\
\hline $\begin{array}{l}\text { Housewives: } \\
\text { Mrs B.: }\end{array}$ & $\begin{array}{l}\text { intake } \\
\text { expenditure }\end{array}$ & $\begin{array}{l}195 I \\
2153\end{array}$ & $\begin{array}{l}2263 \\
1899\end{array}$ & $\begin{array}{l}1943 \\
2024\end{array}$ & $\begin{array}{l}2044 \\
2108\end{array}$ & $\begin{array}{l}1951 \\
\text { r } 963\end{array}$ & $\begin{array}{l}1742 \\
1896\end{array}$ & $\begin{array}{l}2288 \\
1957\end{array}$ & $\begin{array}{l}2026 \\
2000\end{array}$ \\
\hline Mrs C.: & intake & 1467 & 2040 & 2904 & 2155 & I773 & 2214 & $855^{*}$ & 1915 \\
\hline Mrs D.: & $\begin{array}{l}\text { expenditure } \\
\text { intake }\end{array}$ & $\begin{array}{l}\times 433 \\
1841\end{array}$ & $\begin{array}{l}1818 \\
1660\end{array}$ & $\begin{array}{l}2249 \\
2067\end{array}$ & $\begin{array}{l}1807 \\
1650\end{array}$ & $\begin{array}{l}1893 \\
2035\end{array}$ & $\begin{array}{l}1792 \\
2553\end{array}$ & $\begin{array}{l}1354 \\
2187\end{array}$ & $\begin{array}{l}1764 \\
1999\end{array}$ \\
\hline & expenditure & 2295 & 2247 & 2090 & 2245 & 2205 & 1892 & 1865 & 2120 \\
\hline Mrs Dr.: & intake & I 987 & 2377 & 1867 & r 978 & 2057 & 2419 & 1997 & 2097 \\
\hline & expenditure & 2235 & 2326 & 2190 & 2282 & 2197 & 2224 & 1882 & $219 I$ \\
\hline Mrs Du.: & intake & 1966 & 3093 & 1836 & 2327 & 1690 & 3035 & 2545 & 2356 \\
\hline & expenditure & 2164 & 2374 & 2120 & 2442 & 2089 & 2052 & 2234 & $2,2 \times 1$ \\
\hline Mrs G.: & intake & 1946 & 1698 & 2364 & 1994 & 2664 & 2244 & 2823 & 2248 \\
\hline & expenditure & 2455 & I94I & 2096 & 2226 & 1918 & $194^{\circ}$ & $\mathrm{I} 78 \mathrm{I}$ & 2051 \\
\hline Mrs H.: & $\begin{array}{l}\text { intake } \\
\text { expenditure }\end{array}$ & $\begin{array}{l}2157 \\
2066\end{array}$ & $\begin{array}{l}2598 \\
2186\end{array}$ & $\begin{array}{l}2757 \\
2160\end{array}$ & $\begin{array}{l}1907 \\
1927\end{array}$ & $\begin{array}{l}2337 \\
2163\end{array}$ & $\begin{array}{l}2054 \\
2176\end{array}$ & $\begin{array}{l}1900 \\
1878\end{array}$ & $\begin{array}{l}2244 \\
2079\end{array}$ \\
\hline Mrs J.: & $\begin{array}{l}\text { intake } \\
\text { expenditure }\end{array}$ & $\begin{array}{l}1473 \\
2011\end{array}$ & $\begin{array}{l}1854 \\
2012\end{array}$ & $\begin{array}{l}1798 \\
\text { I } 805\end{array}$ & $\begin{array}{l}1745 \\
1821\end{array}$ & $\begin{array}{l}1425 \\
1993\end{array}$ & $\begin{array}{l}\mathbf{6 6 6 9} \\
2226\end{array}$ & $\begin{array}{l}1185 \\
2017\end{array}$ & $\begin{array}{l}1593 \\
1984\end{array}$ \\
\hline Mrs McQ.: & $\begin{array}{l}\text { intake } \\
\text { expenditure }\end{array}$ & $\begin{array}{l}1688 \\
1956\end{array}$ & $\begin{array}{l}2063 \\
1920\end{array}$ & $\begin{array}{l}\text { I I 50 } \\
\text { I } 874\end{array}$ & $\begin{array}{l}1909 \\
1884\end{array}$ & $\begin{array}{l}1760 \\
2162\end{array}$ & $\begin{array}{l}2172 \\
1828\end{array}$ & $\begin{array}{l}2405 \\
1586\end{array}$ & $\begin{array}{l}1878 \\
1887\end{array}$ \\
\hline Mrs S.: & intake & 2066 & 2064 & 2077 & 1818 & 2112 & 1624 & 2270 & 2004 \\
\hline & expenditure & 2339 & 2379 & 2506 & 2411 & 2278 & 2247 & 2083 & 2320 \\
\hline Mrs St.: & intake & 2397 & 2694 & 1822 & 2116 & 2363 & 2699 & 2954 & 2435 \\
\hline & expenditure & 2304 & $244^{\circ}$ & 2310 & $2 \times 40$ & 2382 & 2383 & 2057 & 2288 \\
\hline Mrs W.: & intake & 2542 & 2173 & 2906 & 2360 & 2412 & 2381 & 2108 & 2412 \\
\hline & expenditure & 2287 & 2322 & 2284 & 2176 & 2054 & 2152 & 2033 & 2187 \\
\hline Mean: & intake & 1957 & 2215 & 2124 & 2000 & 2048 & 2234 & 2126 & \\
\hline & expenditure & 2142 & 2 I 55 & 2142 & 2122 & 2108 & 2067 & I894 & \\
\hline
\end{tabular}

Daughters

Grand mean for the week: intake, 2100 ; expenditure, 2090.

\begin{tabular}{|c|c|c|c|c|c|c|c|c|c|}
\hline \multirow[t]{2}{*}{ Jean B.: } & intake & 1520 & 1632 & I 704 & 2314 & 1787 & 1664 & 1820 & 1777 \\
\hline & expenditure & 2118 & 1984 & 2160 & 1939 & 2076 & 2122 & I $79 \mathrm{I}$ & 2027 \\
\hline \multirow[t]{2}{*}{ Margaret C.: } & intake & I583 & 1416 & $253^{8}$ & 2317 & 1938 & 1780 & I3I7 & I 841 \\
\hline & expenditure & $205^{6}$ & 2115 & 2057 & 2040 & 2143 & 1907 & 1645 & I 995 \\
\hline \multirow[t]{2}{*}{ Margaret D. : } & intake & 1893 & 2382 & 2459 & 2400 & 1526 & 1689 & 2,212 & 2080 \\
\hline & expenditure & 2234 & 2299 & 2262 & 2255 & 2227 & 1963 & 1610 & 2121 \\
\hline \multirow[t]{2}{*}{ Elma Dr. } & intake & 2686 & 1909 & 2053 & 1820 & 2203 & 2079 & 1325 & 2011 \\
\hline & expenditure & 2837 & 2979 & 2973 & 2972 & 2889 & 2708 & 2577 & 2848 \\
\hline \multirow[t]{2}{*}{ Muriel Du.: } & intake & 2209 & 2346 & $265 I$ & 2336 & 2234 & 2757 & 2104 & 2377 \\
\hline & expenditure & 2788 & 2525 & 2391 & 2492 & 2521 & 2183 & 1704 & 2372 \\
\hline \multirow[t]{2}{*}{ Sheila G.: } & intake & 244 I & 2595 & 28 I 3 & 2763 & 2851 & 2415 & 3023 & 2700 \\
\hline & expenditure & 2769 & 2713 & $26+5$ & 2591 & 2578 & 2305 & 1907 & 2497 \\
\hline \multirow[t]{2}{*}{ Nada H.: } & intake & 1990 & 2914 & $235^{6}$ & 2465 & 2723 & 2367 & $\times 509$ & 2332 \\
\hline & expenditure & 2279 & 2350 & 2244 & 2234 & 2237 & 2207 & 1850 & 2200 \\
\hline \multirow[t]{2}{*}{ Evelyn J.: } & intake & 2442 & 2568 & 2488 & 2255 & $1337 t$ & $1382 f$ & 1676 & 2021 \\
\hline & expenditure & 1894 & 1867 & 1830 & 1918 & ${ }^{1} 3_{3}$ & 2102 & 1739 & I8I9 \\
\hline \multirow[t]{2}{*}{ Nan McQ.: } & intake & 1608 & 2255 & 1779 & I 883 & I 598 & $205 I$ & 1823 & I 857 \\
\hline & expenditure & $233^{\circ}$ & 2390 & $245^{6}$ & 2262 & 2387 & 2176 & 1967 & $228 I$ \\
\hline \multirow[t]{2}{*}{ Meta S.: } & intake & 2181 & 2339 & I 9 II & 2000 & 2459 & 2702 & 2943 & 2362 \\
\hline & expenditure & $245^{8}$ & 2263 & 2273 & 2408 & 2096 & 1620 & 2783 & 2272 \\
\hline \multirow[t]{2}{*}{ Rita St.: } & intake & 2833 & 2899 & 2993 & 2931 & 2335 & 1978 & 3070 & 2720 \\
\hline & expenditure & 2976 & 2638 & 2917 & $283^{\circ}$ & 2289 & 2462 & I 737 & $255^{\circ}$ \\
\hline \multirow[t]{2}{*}{ Jeanette W.: } & intake & $284^{\circ}$ & 2636 & 2040 & 2592 & 2691 & 2553 & 2532 & 2532 \\
\hline & expenditure & 2031 & 2049 & 2054 & 2079 & 2398 & 2165 & 1691 & 2067 \\
\hline \multirow[t]{2}{*}{ Mean: } & intake & 2186 & 2324 & 2315 & 2340 & 2140 & 2118 & 2113 & \\
\hline & expenditure & 2406 & 2348 & 2353 & 2335 & 2269 & 2160 & 1917 & \\
\hline
\end{tabular}

Grand mean for the week: intake, 2220; expenditure, 2255.

* Stayed in bed all Sunday-'off colour'. Recovered by Monday afternoon. + Slight attack of gastritis. $\quad \ddagger$ Recovery complete by afternoon. 
As an illustration of the energy expended by housewives on various domestic tasks, and the influence of body-weight on this expenditure, Table 3 shows some results obtained on four young housewives who were studied in addition to the mothers and daughters. They were chosen for their widely different weights $(50,56,64$ and $70 \mathrm{~kg})$ and their experience in the use of the respirometer. The various tasks were performed at their own pace of working. McK. has a lower metabolic rate than might be expected, but the other three showed an obvious relation between body-weight and energy cost in almost all the separate activities.

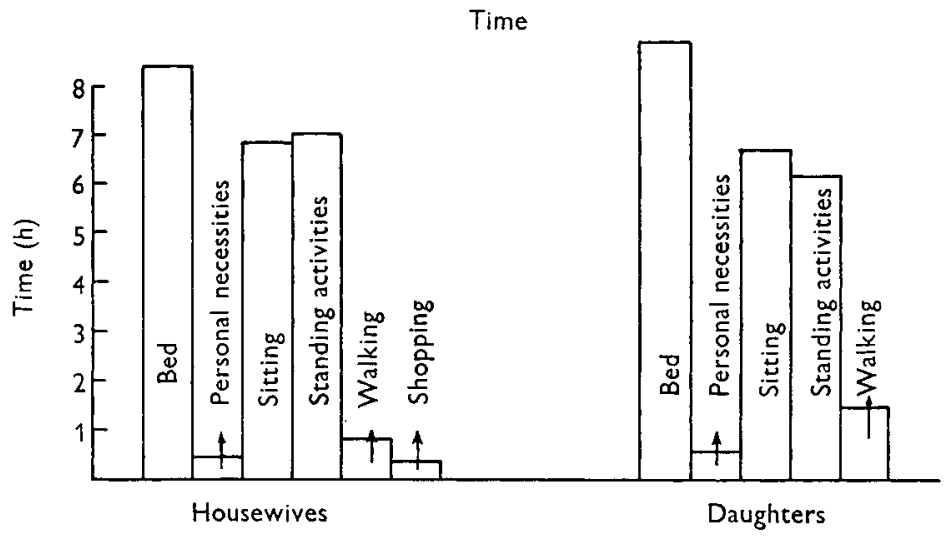

Energy expenditure

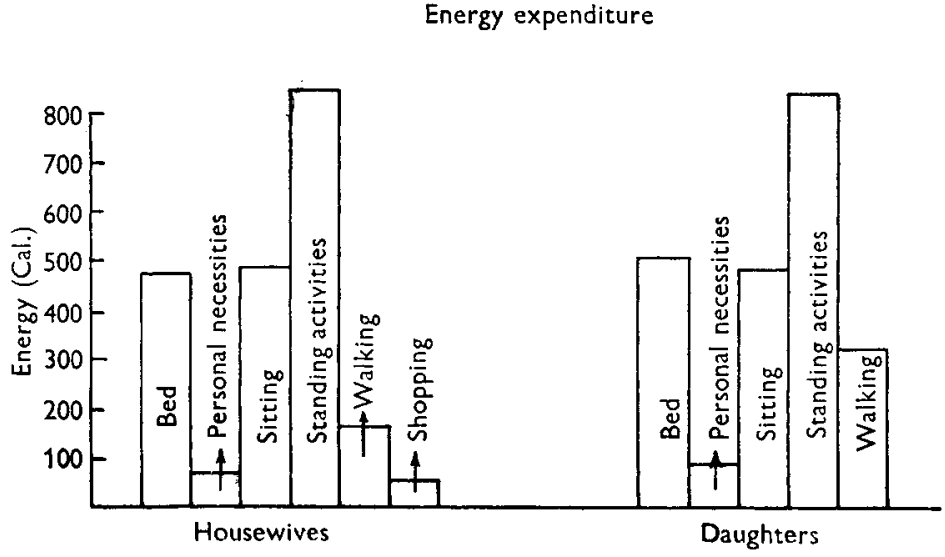

Fig. I. Time and energy expended by middle-aged housewives and their adult daughters in various activities. 'Standing activities' includes housework.

Food intake. The detailed results of the diet survey are discussed in another paper (Durnin, Blake \& Brockway, 1957). Table 4 shows the contribution of protein, fat and carbohydrate to the total energy value of the diets of the housewives and the daughters. The proportions of the different nutrients were almost identical in the two groups. Alcohol is not mentioned in the table. Only in one or two instances were alcoholic drinks taken and then to a very modest extent. 
Table 3. Energy expenditure (Cal./min) of four young housewives in some domestic tasks

\begin{tabular}{|c|c|c|c|c|c|c|c|c|c|c|}
\hline Subject & $\begin{array}{l}\text { Weight } \\
\text { (lb. (kg)) }\end{array}$ & Sitting & Standing & Cooking & $\begin{array}{c}\text { Washing-up } \\
\text { dishes }\end{array}$ & $\begin{array}{l}\text { Setting } \\
\text { table }\end{array}$ & Dusting & $\begin{array}{c}\text { Bed } \\
\text { making }\end{array}$ & Laundry* & $\begin{array}{l}\text { Walking at } \\
3.1 \text { m.p.h. }\end{array}$ \\
\hline \multirow[t]{2}{*}{$\mathrm{C}$} & $109(50)$ & $1 \cdot 23$ & $I \cdot Y I$ & I.88 & $3 \cdot 13$ & $2 \cdot 48$ & $3 \cdot 65$ & $3.9 I$ & $2 \cdot 59$ & 3.80 \\
\hline & & $\begin{array}{r}1 \cdot 19 \\
(1 \cdot 2)\end{array}$ & $\begin{array}{r}r \cdot 37 \\
(x \cdot 3)\end{array}$ & $\begin{array}{c}2 \cdot 29 \\
(2 \cdot 1)\end{array}$ & $\begin{array}{c}2 \cdot 3^{6} \\
(2 \cdot 7)\end{array}$ & $\begin{array}{r}3.03 \\
(2 \cdot 8)\end{array}$ & $\begin{array}{r}3.25 \\
(3.5)\end{array}$ & $\begin{array}{c}3.68 \\
(3 \cdot 8)\end{array}$ & $\begin{array}{c}2 \cdot 47 \\
(2 \cdot 5)\end{array}$ & $\begin{array}{r}3.87 \\
(3.8)\end{array}$ \\
\hline \multirow[t]{2}{*}{$\mathbf{F}$} & $124(56)$ & 0.88 & 0.90 & $2 \cdot 80$ & $2 \cdot 96$ & $3 \cdot 23$ & 3.56 & 5.02 & $3 \cdot 23$ & $4 \cdot 23$ \\
\hline & & $\begin{array}{c}0.73 \\
(0.8)\end{array}$ & $\begin{array}{l}I \cdot 25 \\
(I \cdot I)\end{array}$ & $\begin{array}{r}2 \cdot 40 \\
(2 \cdot 6)\end{array}$ & $\begin{array}{c}2.53 \\
(2.7)\end{array}$ & $\begin{array}{c}2 \cdot 97 \\
(3 \cdot 1)\end{array}$ & $\begin{array}{r}3.52 \\
(3.5)\end{array}$ & $\begin{array}{c}4 \cdot 27 \\
(4 \cdot 6)\end{array}$ & $\begin{array}{c}2 \cdot 88 \\
(3 \cdot I)\end{array}$ & $\begin{array}{r}4 \cdot 37 \\
(4 \cdot 3)\end{array}$ \\
\hline \multirow[t]{2}{*}{$\mathbf{K}$} & $141(64)$ & I. 09 & $1 \cdot 67$ & $2 \cdot 93$ & 3.19 & $3 \cdot 68$ & $3 \cdot 20$ & $4 \cdot 82$ & 3.64 & 4.96 \\
\hline & & $\begin{array}{c}I \cdot I 0 \\
(I \cdot I)\end{array}$ & $\begin{array}{c}I \cdot 48 \\
(I \cdot 6)\end{array}$ & $\begin{array}{r}2 \cdot 62 \\
(2 \cdot 8)\end{array}$ & $\begin{array}{c}2 \cdot 97 \\
(3 \cdot 1)\end{array}$ & $\begin{array}{r}3.45 \\
(3.6)\end{array}$ & $\begin{array}{r}3 \cdot 81 \\
(3.5)\end{array}$ & $\begin{array}{c}3 \cdot 70 \\
(4 \cdot 3)\end{array}$ & $\begin{array}{r}3.24 \\
(3.4)\end{array}$ & $\begin{array}{r}5 \cdot 26 \\
(5 \cdot 1)\end{array}$ \\
\hline \multirow[t]{2}{*}{ McK } & $155(70)$ & $I \cdot 12$ & $1 \cdot 33$ & $2 \cdot 30$ & $3 \cdot 83$ & $3 \cdot 3 I$ & $2 \cdot 9 \mathrm{I}$ & $4 \cdot 8 \mathrm{I}$ & $3 \cdot 36$ & $4 \cdot 78$ \\
\hline & & $\begin{array}{r}1 \cdot 37 \\
(I \cdot 2)\end{array}$ & $\begin{array}{r}r \cdot 4 I \\
(I \cdot 4)\end{array}$ & $\begin{array}{c}2 \cdot 92 \\
(2 \cdot 6)\end{array}$ & $\begin{array}{c}2 \cdot 6 \mathrm{I} \\
(3 \cdot 2)\end{array}$ & $\begin{array}{r}3.55 \\
(3.4)\end{array}$ & $\begin{array}{r}3.93 \\
(3.4)\end{array}$ & $\begin{array}{r}3 \cdot 44 \\
(4 \cdot 1)\end{array}$ & $\begin{array}{r}3 \cdot 11 \\
(3 \cdot 2)\end{array}$ & $\begin{array}{c}4 \cdot 84 \\
(4 \cdot 8)\end{array}$ \\
\hline
\end{tabular}

Mean values are given in parentheses.

The duplicate measurements were all done on different days.

* Including putting the clothes in the boiler, washing, wringing, rinsing and hanging up the clothes to dry.

Table 4. Contribution of protein, fat and carbohydrate to the total energy value of the diets of middle-aged housewives and their adult daughters

\begin{tabular}{|c|c|c|c|c|}
\hline \multirow[b]{3}{*}{ Nutrient } & \multicolumn{4}{|c|}{ Mean daily contribution to calorie intake of } \\
\hline & \multicolumn{2}{|c|}{ Housewives } & \multicolumn{2}{|c|}{ Daughters } \\
\hline & Cal./head & $\begin{array}{c}\text { Percentage } \\
\text { of total }\end{array}$ & Cal./head & $\begin{array}{l}\text { Percentage } \\
\text { of total }\end{array}$ \\
\hline Protein & 264 & $12 \cdot 6$ & 273 & $12 \cdot 3$ \\
\hline Fat & 850 & $40 \cdot 5$ & 873 & $39 \cdot 3$ \\
\hline Carbohydrate & 986 & $46 \cdot 9$ & 1074 & $48 \cdot 4$ \\
\hline Total & 2100 & $100 \cdot 0$ & 2220 & $100 \cdot 0$ \\
\hline
\end{tabular}

\section{DISCUSSION}

The results show an apparently low intake and expenditure of energy by the housewives. The mean value of $2100 \mathrm{Cal}$./day would classify the housewife, according to the B.M.A. scale (British Medical Association: Committee on Nutrition, 1950) and taking account of the weights of the subjects, as a sedentary worker. The shop-girls, although they were more than $17 \mathrm{lb}$. $(7.5 \mathrm{~kg})$ lighter and expended very little more energy in recreation than did the mothers, had a somewhat higher total energy output. By no stretch of imagination can one call housewives sedentary workers. Obviously the B.M.A. recommendation for sedentary female workers is too high. On the other hand, the figure of 1950 Cal./day given by Jolliffe (1952) for American housewives in our height and age group, is probably an underestimate, even allowing for differences in household work in the two countries. Both the B.M.A. and the Jolliffe recommendations have been built up from guesses at the energy requirements during the hypothetical basal state plus an allowance for specific dynamic action plus an allowance for activity. This method of constructing a total for energy needs over $24 \mathrm{~h}$ was also used in the FAO Report (FAO: Committee on Calorie Requirements, I950). The 
essential item in these calculations is the basal metabolic rate (B.M.R.). Both the concept and the practical value of basal metabolism have been much criticized lately. It would appear that many studies on the B.M.R. have been subjected to mathematical treatment without adequate critical assessment of the validity of the original data. Often, the original studies left much to be desired in the selection of subjects and little attempt was made to ensure that results were reproducible.

Similarly, any allowance for specific dynamic action (S.D.A.) is also subject to a wide error; in any event, recent determinations of energy expenditure in field studies have usually been carried out without regard to recent food intake and so include any S.D.A. effect that may have been present.

Apart from theoretical objections to using the B.M.R. as a basis for estimating total energy requirements, unnecessary difficulties arise in practice. Actual measurement of the energy cost of any activity is always initially a gross value; it is quite superfluous, and indeed misleading, to deduct some predicted estimate for basal or resting metabolism in order to convert this gross figure into a net value.

In an appendix to the FAO Report (FAO: Committee on Calorie Requirements, 1957) details are given of a different method of calculating the total energy expenditure. The $24 \mathrm{~h}$ of the day are divided into $8 \mathrm{~h}$ in bed, $8 \mathrm{~h}$ at work, and the remaining $8 \mathrm{~h}$ are divided into times spent in several non-occupational activities (which, for women, may include extra domestic work). An overall 'calorie value' is allotted to each of these and the total estimated. In this way, an allowance is calculated for a reference woman, aged 25, and engaged in ordinary housework, of $2300 \mathrm{Cal}$./day.

The report of the FAO: Committee on Calorie Requirements (1950) advocated a decrement of $7.5 \%$ in calorie intake for each decade beyond the age of 25 years. The Fourth Report of the FAO/WHO: Joint Expert Committee on Nutrition (1955) states that 'a decrement of about $3 \%$ for each decade would be more suitable, as far as the United Kingdom is concerned, than the recommended figure of $7 \frac{1}{2} \%$. A decrement of $3 \%$ per decade beyond the age of 25 years, when applied to the $2300 \mathrm{Cal}$./day of the FAO 'reference woman', gives a value of $2130 \mathrm{Cal}$. at age 50 , which is very near that of the housewives in the present survey. A comparison of the mothers and daughters can be made by applying the same decrement to the $2255 \mathrm{Cal}$./ day expended by the daughters. It seems reasonable to assume, from the energy cost of the several activities involved and the time spent in each (Fig. I) that, at least in the present study, the energy expenditure of a housewife was similar to that of a shopassistant. If this assumption involves no large error, then the mothers and daughters may be compared from the aspect of age alone. A $3 \%$ decrement per decade over 25 off $2255 \mathrm{Cal}$./day leaves a value of approximately $2085 \mathrm{Cal}$, which again is very similar to the $2090 \mathrm{Cal}$. expended daily by the mothers. Although the present results are very limited in their general application, they provide some evidence in support of the suggested $3 \%$ decrease in calorie allowances. Until we have more information it will not be possible to say what the decrement for age will be beyond the age of 55 . $U p$ to the age of 55 , however, for women who are not engaged in much hard physical work, a decrement of $3 \%$ per decade beyond the age of 25 would appear a reasonable value to use. 
Although the energy expenditure in housework in the present survey may appear lower than might have been expected, it is in keeping with the calorie intake of middle-class women (Widdowson \& McCance, 1936). That most people tend to think of housework as hard work is probably due to several reasons. It is certainly mentally fatiguing. There is also some emotional justification for regarding it as 'heavy'undoubtedly many tasks involved in running a house demand individually considerable muscular effort. For example, climbing stairs, cleaning windows, washing clothes and scrubbing floors are all activities which come into this category. Yet the time spent in all such tasks, when averaged over the week, is very small. Very careful and ingenious measurements have been made by Bateson, Noble \& Attenburrow (1954) at the Building Research Station, of the distance walked by the housewife in the home. This distance amounts, on the average, to no more than $\mathrm{r}_{4}^{\frac{1}{4}}$ miles daily. Similarly, if the stairs are climbed thirty times a day, the total time spent in both going up and coming down will probably not amount to more than Io min. So also with most of the 'heavy' work in the home. The result is that the total energy expended in all the heavy tasks does not have a great influence on the total daily energy expenditure.

\section{SUMMARY}

I. The individual intakes and expenditures of energy of middle-aged, middle-class housewives and of their adult working daughters were measured daily for 7 consecutive days. Twelve mother-daughter pairs were studied. The girls all worked as saleswomen in a large departmental store in Glasgow.

2. The mean daily intake of calories was $2100 \mathrm{Cal}$. for the mothers and 2225 for the daughters; the mean expenditures were 2090 and $2255 \mathrm{Cal}$./day respectively.

3. A table is given to show the individual daily variation in the intake and expenditure of calories. The pattern of the activities of both groups is also shown.

4. Possible explanations for the quite moderate demands of housework on energy expenditure are discussed.

5. Since the activities of mothers and daughters were not unlike in terms of energy expenditure, it was possible to derive the decrement in calorie expenditure due to age: a decrement of $3 \%$ for each decade over the age of 25 years is in keeping with our results.

We wish to record our gratitude to the subjects who put up with some personal inconvenience in order to partake in this survey, to the owners and management of Pettigrews Ltd where the girls worked, to the Principal, Miss Andross, Miss Forrest and the dietitians from the Glasgow and West of Scotland College of Domestic Science, and to Miss Couperwhite. We are also grateful to Professor R. C. Garry for advice.

The survey was financed by the Scottish Hospital Endowments Research Trust. 


\title{
REFERENCES
}

Bateson, R. G., Noble, K. J. \& Attenburrow, J. J. (1954). J. R. Inst. Brit. Archit. 62, 66.

British Medical Association: Committee on Nutrition (1950). Report of the Committee on Nutrition. London: British Medical Association.

Buskirk, E. R., Kreider, M., Brebbia, R., Morana, N., Daniels, F., Welch, B. E., Mann, J. B., Insull, W. \& Friedemann, T. E. (1956). Tech. Rep. EP-33, Quartermaster Research and Development Command.

Consolazio, C. F., Pollack, H., Crowley, L. V. \& Goldstein, D. R. (1956). Metabolism, 5, 259.

Durnin, J. V. G. A. (1955). F. Physiol. 128, 294.

Durnin, J. V. G. A. \& Edwards, R. G. (1955). Quart. F. exp. Physiol. 40, 370.

Durnin, J. V. G. A., Blake, E. C. \& Brockway, J. M. (1957). Brit. F. Nutr. II, 94.

Edholm, O. G., Fletcher, J. G., Widdowson, E. M. \& McCance, R. A. (1955). Brit. F. Nutr. $9,286$.

Fleisch, A. (1951). Helv. med. acta, 18, 23.

FAO: Committee on Calorie Requirements (1950). F.A.O. nutr. Stud. no. 5.

FAO: Committee on Calorie Requirements (I957). (In the Press.)

FAO/WHO: Joint Expert Committee on Nutrition (1955). Tech. Rep. Wld Hlth Org. no. 97.

Garry, R. C., Passmore, R., Warnock, G. M. \& Durnin, J. V. G. A. (1955). Spec. Rep. Ser. med. Res. Coun., Lond., no. 289.

Jolliffe, N. (1952). Quart. Bull. N.Y. Cy Dep. Hlth, 20, 26.

Medical Research Council: Accessory Food Factors Committee (1945). M.R.C. (War) Memor. no. 44.

Müller, E. A. \& Franz, H. (1952). Arbeitsphysiologie, 14, 499.

Passmore, R., Thomson, J. G. \& Warnock, G. M. (I952). Brit. F. Nutr. 6, 253.

Passmore, R. \& Durnin, J. V. G. A. (1955). Physiol. Rev. 35, 80I.

Sargent, F., Sargent, V. W., Johnson, R. E. \& Stolpe, S. G. (1954). WADC Tech. Rep. 53-484, Part I.

Sargent, F., Sargent, V. W., Johnson, R. E. \& Stolpe, S. G. (1955). WADC Tech. Rep. 53-484, Part II.

Widdowson, E. M. \& McCance, R. A. (1936). F. Hyg., Camb., 36, 293.

\section{The diets of middle-aged Glasgow housewives and their adult daughters}

\author{
By J. V. G. A. DURNIN, ELAINE C. BLAKE AND J. M. BROCKWAY \\ Institute of Physiology, University of Glasgow
}

(Received 1o November 1956)

In an earlier paper (Durnin, Blake \& Brockway, 1957) the intake and expenditure of energy of two groups of women are discussed. This paper gives further information about their diets.

\section{EXPERIMENTAL}

The food intake of twelve middle-aged, middle-class Glasgow housewives and their twelve adult daughters was measured daily for I week by the individual inventory method. Details of the subjects and of the method of the investigation are given in the earlier paper (Durnin et al. 1957).

\section{RESULTS AND DISCUSSION \\ Pattern of the meals}

The pattern of eating was typical for Scotland: breakfast, dinner in the middle of the day and high tea in the evening; the last two were main meals and included a dish of cooked foods rich in protein. Snacks were often taken at mid-morning, in the after- 